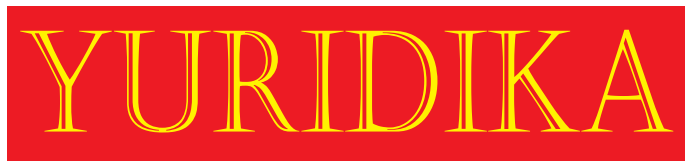

Volume 33 No. 2, Mei 2018

DOI: $10.20473 /$ ydk.v33i2.7414

Fakultas Hukum Universitas Airlangga, Jalan Dharmawangsa Dalam Selatan

Surabaya, 60286 Indonesia, +6231-5023151/5023252

Fax+6231-5020454, E-mail: yuridika@fh.unair.ac.id Yuridika (ISSN: 0215-840X | e-ISSN: 2528-3103)

FAKULTAS HUKUM UNIVERSITAS AIRLANGGA $\begin{aligned} & \text { by http://e-journal.unair.ac.id/index.php/YDK/index under a Creative } \\ & \text { Commons Attribution-NonCommercial-ShareAlike 4.0 }\end{aligned}$

Article history: Submitted 19 January 2018; Accepted 14 March 2018; Available Online 1 May 2018

\title{
KOMPENSASI DAN RESTITUSI YANG BERORIENTASI PADA KORBAN TINDAK PIDANA
}

\author{
Mahrus Ali dan Ari Wibowo \\ mahrus_ali@uii.ac.id \\ Universitas Islam Indonesia
}

\begin{abstract}
The study proposes the compensation and restitution regulations which should be oriented to protect the victim of crime. Although most regulations have been adopted the right of the victims to receive the compensation and restitution, but this study finds that there are some weaknesses in such regulations. Hence, compensation regulation should be specifically focused on the fulfilment of the right of the victims of crime. It shall not depend on court decisions, but such compensation should be provided even though the victims ceased before the court proceeding has started, or even if he or she wrongly arrested by police. This compensation is only to cover material losses and traumatic stress recovery cost. It could be paid directly monthly or yearly and could be converted to other form of compensation. Restitution refers to the paradigm of restorative justice. In Indonesia, restitution should be based on final and binding court decision. If the perpetrator does not want to provide it for the victim, he/she has moral obligation to provide it for the victim oven without inkracht court decision, and this could be used by the judges to pardon the perpetrator. Restitution shall be enforced for all criminal offences which resulting direct and indirect losses for the victims. Restitution is not merely about monetary values but moral obligation of the perpetrator to recover the victim's condition.
\end{abstract}

Keywords: Compensation; Restitution; Victim of Crime.

\begin{abstract}
Abstrak
Tulisan ini menggagas pengaturan kompensasi dan restitusi yang berorientasi pada perlindungan terhadap korban tindak pidana. Meskipun berbagai perundang-undangan telah mengakomodir hak korban untuk memperoleh kompensasi dan restitusi, tapi pengaturannya masih mengandung kelemahan. Oleh karena itu, pembaharuan pengaturan kompensasi difokuskan pada pemenuhan hak-hak korban yang dilanggar oleh negara. Ia tidak perlu bergantung kepada putusan pengadilan, diberikan kepada korban suatu tindak pidana yang pelakunya meninggal dunia sebelum proses peradiilan selesai atau digelar, atau korban salah tangkap penegak hukum. Kompensasi hanya pada kerugian materiil dan biaya pemulihan trauma atau stres, bisa dibayar langsung, dibayar tiap bulan/ tahun, serta dapat dikonversi ke dalam bentuk lain. Restitusi mengacu kepada paradigma keadilan restoratif. Ketentuan mengenai keharusan adanya putusan pengadilan yang berkekuatan hukum tetap baru dilaksanakan bila pelaku tidak mau membayar restitusi. Pelaku bahkan dapat memberikan restitusi kepada korban sebelum adanya putusan tersebut dan dapat dijadikan sebagai hal yang meringankan atau pemaafan hakim. Restitusi berlaku untuk semua tindak pidana yang menimbulkan kerugian korban secara langsung dan bentuknya tidak harus uang, dan keberadaannya tidak hanya sekedar uang, tapi kewajiban moral pelaku untuk memperbaiki kondisi korban.
\end{abstract}

Kata Kunci: Kompensasi; Restitusi; Korban. 


\section{Pendahuluan}

Selama ini keberadaan korban (victim) dalam suatu tindak pidana tidak terlalu mendapatkan perhatian. Hukum pidana lebih cenderung memberikan perhatian yang besar terhadap pelaku tindak pidana dibanding korbannya. Korban hanya diposisikan sebagai pelapor dan saksi suatu tindak pidana. ${ }^{1}$ Padahal korban merupakan objek yang mengalami penderitaan akibat tindak pidana baik fisik maupun psikis. Dalam hukum pidana, korban diabstraksikan menjadi kepentingan umum atau masyarakat sehingga ketika terjadi suatu tindak pidana dan pelakunya telah dipidana, maka diasumsikan korban telah mendapatkan perlindungan. ${ }^{2}$ Hukum pidana seolah menelantarkan korban karena tidak mempedulikan pemulihan terhadap kerugian yang dideritanya akibat suatu tindak pidana. ${ }^{3}$

Kitab Undang-undang Hukum Pidana (selanjutnya disebut KUHP) yang merupakan induk hukum pidana Indonesia lebih banyak mengatur aspek yang berhubungan dengan pelaku tindak pidana. Angkasa dengan mengutip pendapat Sudarto menyatakan bahwa KUHP menganut aliran neoklasik yang antara lain menerima keadaan-keadaan yang meringankan pelaku tindak pidana, sementara korban cenderung dilupakan. Sama halnya dengan pengaturan dalam KUHAP yang didominasi ketentuan mengenai hak-hak pelaku tindak pidana, dan sedikit sekali yang menyinggung hak-hak korban. ${ }^{4}$ Ketentuan KUHAP yang mengatur aspek korban hanya terdapat dalam Bab XII mengenai penggabungan perkara gugatan ganti kerugian, Pasal 108 mengenai hak melaporkan atau mengadukan tindak pidana, Pasal 134 ayat 1 mengenai hak keluarga korban untuk diberitahu apabila korban meninggal dunia, dan Pasal 299 ayat 1 tentang hak korban sebagai saksi untuk mendapatkan penggantian biaya ketika memenuhi panggilan untuk menyampaikan keterangan. ${ }^{5}$

\footnotetext{
${ }^{1}$ Karyn Ellen Polito, 'The Rights of Crime Victims in the Criminal Justice System: Is Justice Blind to the Victims of Crime?' (1990) 16 New England Journal on Criminal and Civil Confinement. [242-243].

${ }^{2}$ Susan E. GeganNicholas Ernesto Rodriguez, 'Victims' Roles in the Criminal Justice System: A Fallacy of Victim Empowerment?' (1992) 8 Saint John's Journal of Legal Commentary.[230].

${ }^{3}$ Karyn Ellen Polito.[243-244].

4 Angkasa, 'Kedudukan Korban Dana Sistem Peradilan Pidana', Pelatihan Viktimologi Indonesia (Universitas Jenderal Soedirman 2016).[10].

${ }^{5}$ ibid.[17].
} 
Dalam beberapa tahun belakangan ini, perhatian hukum pidana terhadap korban sudah mulai tampak. Kejahatan tidak lagi dikonsepsikan sebagai pelanggaran terhadap kepentingan negara, tapi melanggar dan merugikan korban. ${ }^{6}$ Perubahan ini juga dapat dilihat dari beberapa undang-undang yang mencantumkan ketentuan perlindungan terhadap korban tindak pidana. Beberapa undang-undang tersebut, misalnya UU No. 26 Tahun 2000 Tentang Pengadilan Hak Asasi Manusia, UU No. 15 Tahun 2003 Tentang Pemberantasan Tindak Pidana Terorisme, UU No. 23 Tahun 2004 Tentang Penghapusan Kekerasan dalam Rumang Tangga, UU No. 21 Tahun 2007 Tentang Pemberantasan Tindak Pidana Perdagangan Orang, UU No. 8 Tahun 2010 Tentang Pencegahan dan Pemberantasan Tindak Pidana Pencucian Uang, serta UU No. 13 Tahun 2014 sebagaimana telah diubah dengan UU No. 31 Tahun 2014 Tentang Perlindungan Saksi dan Korban. Pengaturan tentang hak-hak korban dalam beberapa undangundang tersebut diatur lebih lanjut dalam peraturan pelaksananya. ${ }^{7}$

Salah satu pertimbangan pentingnya perlindungan terhadap korban adalah karena kerugian yang dideritanya. Oleh karena itu, bentuk perlindungan terhadap korban yang sangat esensial dilakukan melalui pemulihan kerugian yang diderita korban akibat suatu tindak pidana. Pemulihan tersebut bisa berupa kompensasi atau restitusi. Pentingnya kompensasi dan restitusi dalam rangka memberikan perlindungan terhadap korban telah dicantumkan dalam Declaration of Basic Principles of Justice for Victims of Crime and Abuse of Power tahun 1985, yaitu pada Pasal 8 sampai Pasal 11 tentang restitusi, dan Pasal 12 sampai Pasal 13 tentang kompensasi. Sebagai contoh terdapat Pasal 8 yang berbunyi:

\footnotetext{
${ }^{6}$ Juan Cardenas, 'The Crime Victim in the Prosecutorial Process' (1986) 9 Harvard Journal of Law \& Public Policy.[359-360].

${ }^{7}$ Peraturan pelaksana yang sudah ada, misalnya PP No. 2 Tahun 2002 Tentang Tata Cara Perlindungan terhadap Korban dan Saksi dalam Pelanggaran Hak Asasi Manusia yang Berat, PP No. 3 Tahun 2002 Tentang Kompensasi, Restitusi, dan Rehabilitasi terhadap Korban Pelanggaran Hak Asasi Manusia yang Berat, PP No. 24 Tahun 2003 Tentang Tata Cara Perlindungan terhadap Saksi, Penyidik, Penuntut Umum, dan Hakim dalam Perkara Tindak Pidana Terorisme, PP No. 4 Tahun 2006 Tentang Penyelenggaraan dan Kerjasama Pemulihan Korban Kekerasan dalam Rumah Tangga, PP No. 9 Tahun 2008 Tentang Tata Cara dan Mekanisme Pelayanan Terpadu bagi Saksi dan/atau Korban Tindak Pidana Perdagangan Orang, dan PP No. 44 Tahun 2008 Tentang Pemberian Kompensasi, Restitusi, dan Bantuan kepada Saksi dan Korban.
} 
"Offenders or third parties responsible for their behaviour should, where appropriate, make fair restitution to victims, their families or dependants. Such restitution should include the return of property or payment for the harm or loss suffered, reimbursement of expenses incurred as a result of the victimization, the provision of services and the restoration of rights".

Sedangkan Pasal 12 berbunyi:

"When compensation is not fully available from the offender or other sources, States should endeavour to provide financial compensation to: (a) Victims who have sustained significant bodily injury or impairment of physical or mental health as a result of serious crimes; (b) The family, in particular dependants of persons who have died or become physically or mentally incapacitated as a result of such victimization".

Berdasarkan rumusan kedua pasal di atas dapat dipahami bahwa pelaku tindak pidana atau pihak lain yang bertanggung jawab harus memberikan restitusi kepada korban atau keluarganya termasuk ganti kerugian atas harta benda yang rusak atau hilang, ganti kerugian untuk pemulihan penderitaan, dan hak-hak korban lainnya. Adapun jika restitusi tidak dipenuhi oleh pelaku tindak pidana atau pihak lain yang bertanggung jawab, maka negara harus mengambil alih restitusi tersebut dengan memberikan kompensasi kepada korban.

Kompensasi dan restitusi di Indonesia telah diatur dalam beberapa undangundang pidana khusus di luar KUHP, seperti UU No. 26 Tahun 2000 Tentang Pengadilan Hak Asasi Manusia, UU No. 15 Tahun 2003 Tentang Pemberantasan Tindak Pidana Terorisme, dan UU No. 21 Tahun 2007 Tentang Pemberantasan Tindak Pidana Perdagangan Orang. Kompensasi dan restitusi juga diatur dalam undangundang payung terkait perlindungan saksi dan korban, yaitu UU No. 13 Tahun 2006 sebagaimana telah diubah dengan UU No. 31 Tahun 2014 Tentang Perlindungan Saksi dan Korban (selanjutnya disebut UU PSK). Pada UU PSK, restitusi didefinisikan sebagai ganti kerugian yang diberikan kepada korban atau keluarganya oleh pelaku atau pihak ketiga, sedangkan kompensasi diartikan ganti kerugian yang diberikan oleh negara karena pelaku tidak mampu memberikan ganti kerugian sepenuhnya yang menjadi tanggung jawabnya kepada korban atau keluarganya.

Menurut Pasal 7A ayat 1 UU PSK, korban tindak pidana berhak memperoleh restitusi berupa: a) ganti kerugian atas kehilangan kekayaan atau penghasilan; b) ganti 
kerugian yang ditimbulkan akibat penderitaan yang berkaitan langsung sebagai akibat tindak pidana; dan/atau c) penggantian biaya perawatan medis dan/atau psikologis.

Korban pelanggaran hak asasi manusia yang berat dan korban tindak pidana terorisme, selain berhak mendapatkan restitusi, juga berhak mendapatkan kompensasi yang dapat diajukan melalui Lembaga Perlindungan Saksi dan Korban (LPSK). ${ }^{8}$ Sebelumnnya, ketentuan hukum acara pemberian kompensasi dan restitusi diatur dalam Peraturan Pemerintah No. 44 Tahun 2008 Tentang Pemberian Kompensasi, Restitusi, dan Bantuan Kepada Saksi dan korban. Saat ini ketentuan tersebut telah diatur dalam UU No. 31 Tahun 2014 karena ketentuan yang terkait hukum acara seharusnya tidak diatur melalui peraturan pemerintah namun undang-undang agar lebih mengikat.

Berdasarkan Pasal 7A UU PSK, pengajuan permohonan restitusi dapat dilakukan melalui LPSK baik sebelum maupun setelah putusan pengadilan yang telah memperoleh kekuatan hukum tetap. Dalam hal permohonan restitusi diajukan sebelum putusan pengadilan yang telah memperoleh kekuatan hukum tetap, LPSK dapat mengajukan restitusi kepada penuntut umum untuk dimuat dalam tuntutannya. Dalam hal permohonan restitusi diajukan setelah putusan pengadilan yang telah memperoleh kekuatan hukum tetap, LPSK dapat mengajukan restitusi kepada pengadilan untuk mendapat penetapan. Sama halnya dengan restitusi, korban pelanggaran hak asasi manusia yang berat dan korban tindak pidana terorisme dapat mengajukan kompensasi ke Pengadilan melalui LPSK. Pelaksanaan pembayaran kompensasi tersebut diberikan oleh LPSK berdasarkan putusan pengadilan yang telah memperoleh kekuatan hukum tetap.

Meskipun telah ada pengaturannya dalam UU PSK, namun dalam pelaksanaannya, pemberian kompensasi dan restitusi masih terdapat kendala-kendala regulasi, sehingga tidak bisa maksimal dalam memberikan perlindungan terhadap korban, seperti keharusan melalui penetapan pengadilan dan eksekusinya. Kendala ini menunjukkan bahwa pengaturan kompensasi dan restitusi dalam pelbagai perundang-

${ }^{8}$ Pasal 7 ayat 1 UU PSK. 
undangan belum sepenuhnya berorientasi pada perlindungan terhadap korban tindak pidana. Oleh karena itu, penting untuk diteliti secara komprehensif pengaturan dan gagasan pembaharuan pengaturan kompensasi dan restitusi di Indonesia yang berorientasi pada perlindungan terhadap korban tindak pidana.

\section{Kompensasi dan Restitusi dalam Perspektif Teoritis}

Berbeda dengan restitusi yang dibayarkan oleh pelaku atau pihak ketiga, kompensasi justru dibayarkan dan menjadi kewajiban/tanggung jawab negara. Kewajiban negara untuk memberikan kompensasi kepada korban atas tindak pidana yang dilakukan oleh pelaku kejahatan didasarkan kepada teori kegagalan untuk melindungi. Teori ini menyatakan bahwa seorang individu yang menjadi korban suatu tindak pidana pada dasarnya disebabkan oleh kegagalan masyarakat untuk mengeliminasi kejahatan dan kegagalan penegakan hukum untuk mencegah suatu tindak pidana. ${ }^{9}$ Selain itu, ada dua argumentasi mengapa korban berhak atas kompensasi yang diberikan negara. Pertama, kompensasi berbasis pada kewajaran dan solidaritas sosial. Teori ini menyatakan bahwa korban kejahatan sebenarnya merupakan korban masyarakat dan seharusnya dikompensasi oleh masyarakat atas kerugian-kerugian yang diderita. Dalam arti yang lebih luas, teori ini menyatakan bahwa pemerintah memiliki tanggung jawab untuk mengkompensasi korban karena aparat penegak hukum gagal untuk mencegah terjadinya kejahatan. Kedua, sumber-sumber kompensasi yang lain terbukti tidak memadai untuk memberikan kompensasi secara penuh kepada korban. ${ }^{10}$

Kompensasi merupakan skema yang terkait dengan pemberian dana-dana publik kepada seseorang yang menjadi korban suatu kejahatan. Hal penting yang perlu dicatat di sini adalah bahwa dana tersebut merupakan dana publik yang dapat berasal dari

\footnotetext{
${ }^{9}$ Julie Goldscheid, 'Crime Victim Compensation an a Post-9/11 World' (2004) 167 Tulane Law Review.[184].

${ }^{10}$ Nicholas C Katsoris, 'The European Convention on the Compensation of Victims of Violent Crimes: A Decade of Frustration' (1990) 14 Fordham International Law Journal.[189].
} 
sumber eksternal kejahatan dan diberikan atas kebutuhan-kebutuhan khusus korban. ${ }^{11}$ Pemberian kompensasi kepada korban bertujuan untuk memastikan adanya respon yang lebih efektif kepada korban dalam sistem peradilan pidana. ${ }^{12}$ Kompensasi yang diberikan kepada korban meliputi biaya berobat, konseling kesehatan mental, biaya pemakaman, kehilangan gaji, biaya pembelian kacamata, lensa kontak, perawatan gigi, pembelian alat-alat prostetik, biaya berpindah atau relokasi, biaya transportasi untuk memperoleh perawatan medis, rehabilitasi pekerjaan, layanan pengganti bagi perawatan bayi/anak-anak, dan bantuan domestik. ${ }^{13}$

Restitusi muncul ketika gerakan terhadap hak-hak korban memunculkan sentimen bahwa sistem peradilan pidana terlalu menitikberatkan kepada pelaku kejahatan, dan seringkali gagal untuk memenuhi kepentingan dan kebutuhan korban kejahatan. ${ }^{14}$ Gerakan ini pada gilirannya menghasilkan kesadaran yang lebih besar atas kebutuhan dan perhatian terhadap korban dalam sistem peradilan pidana. ${ }^{15}$ Korban kejahatan seringkali diperlakukan secara tidak tepat dan diabaikan dalam sistem peradilan pidana yang seharusnya menyedikan dukungan, informasi dan asistensi. ${ }^{16}$ Pada konteks inilah, restitusi sebenarnya merupakan bagian kecil dari upaya untuk memenuhi hak-hak korban. Melalui restitusi pelaku kejahatan dimintai pertanggungjawaban atas kerugian yang dialami korban.

Dalam hukum pidana restitusi terkait upaya untuk merestorasi kondisi korban kepada situasi sebelum mengalami sejumlah kerugian karena menjadi korban suatu kejahatan. ${ }^{17}$ Hal tersebut merupakan mekanisme yang jamak digunakan dalam proses persidangan di pengadilan untuk merestorasi korban atas kehilangan/

\footnotetext{
${ }^{11}$ Frédéric Mégret, 'Justifying Compensation By The International Criminal Court's Victims Trust Fund: Lessons From Domestic Compensation Schemes' (2010) 36 Brooklyn Journal of International Law.[130-131].

${ }^{12}$ Lieutenant Colonel Warren G Foote, 'State Compensation for Victims of Crime' (1992) March Army Lawyer.[51].

${ }^{13}$ ibid.

${ }^{14}$ Marcus A Asner,[et.,al.], 'Restitution From the Victim Perspective-Recent Developments And Future Trends' (2013) 26 Federal Sentencing Reporter.[59].

${ }^{15}$ Linda F Frank, 'The Collection of Restitution: An Often Overlooked Service to Crime Victims' [1992] Saint John's Journal of Legal Commentary.[111].

16 ibid.[107].

${ }^{17}$ Marcus A Asner,[et.,al.].Op.Cit.[60].
} 
kerugian/kerusakan yang dialaminya. ${ }^{18}$ Restitusi diartikan sebagai "tindakan mengerjakan hal-hal yang baik atau memberikan jumlah yang sama atas kehilangan, kerusakan, atau luka yang dialami oleh korban”. Restitusi diberikan oleh pelaku kejahatan kepada korbannya. Ketika korban mengalami kerugian dan pelakunya teridentifikasi, pelaku dibebani kewajiban untuk membayar sejumlah uang kepada korban. Restitusi dapat meliputi pengembalian sejumlah uang atau nilai suatu objek yang diambil oleh pelaku, biaya pemakaman, hilangnya gaji, dukungan dan pembayaran atas pengeluaran medis, konseling, terapi, atau mencarikan korban suatu pekerjaan baru. ${ }^{19}$ Restitusi hanya dibayarkan oleh pelaku atau pihak ketiga setelah adanya putusan pengadilan yang telah berkekuatan hukum tetap. ${ }^{20}$ Dengan kata lain, pelaku kejahatan harus dinyatakan terbukti bersalah melakukan suatu tindak pidana agar restitusi bisa diklaim oleh korban.

Restitusi mewujudkan beberapa tujuan. Pertama, restitusi berfungsi baik untuk mengganti kerugian yang dialami korban maupun untuk memidana pelaku. Kedua, kemampuan restitusi untuk menelusuri kerugian yang disebabkan oleh (pelaku) kejahatan berfungsi sebagai instrumen pencegahan karena memberikan peringatan kepada pelaku potensial bahwa mereka juga akan dimintai pertanggungjawaban atas setiap kerugian yang ditimbulkan. Ketiga, restitusi juga memaksa pelaku kejahatan untuk mengakui kerugian yang disebabkan perbuatannya dengan memerintahkannya membayar sejumlah uang kepada korban. Kondisi ini menjadikan pelaku secara khusus bertanggungjawab atas apa yang telah diperbuat. Tidak seperti denda yang dibayarkan pelaku kepada negara, restitusi lebih banyak bersifat intim karena diberikan secara langsung oleh pelaku kepada korban dan keberadaannya secara

\footnotetext{
${ }^{18}$ Cortney E Lollar, 'What Is Criminal Restitution?' (2014) 93 Iowa Law Review.[99-100].

${ }^{19}$ Bridgett N Shephard, 'Classifying Crime Victim Restitution: The Theoretical Arguments and Practical Consequences of Labeling Restitution As Either A Criminal or Civil Law Concept' (2014) 18 Lewis\& Clark Law Review < https://law.lclark.edu/live/files/18298-lcb183art15shephardfinalpdf $>$."type" : "article-journal", "volume" : "18" \}, "uris" : ["http://www.mendeley.com/documents/?uuid=7e609e29b722-4ac5-89a3-a072b5d9df91"]\}], "mendeley" : ‘"formattedCitation" : "Bridgett N Shephard,। u2018Classifying Crime Victim Restitution: The Theoretical Arguments and Practical Consequences of Labeling Restitution As Either A Criminal or Civil Law Conceptlu2019 (2014[804]. Benedict J Monachino, ' 'Enhancing Victims' Rights Crime Victims Compensation' [2008] New York State Bar Journal.[37].

${ }^{20}$ Dennis F DiBari, 'Restoring Restitution: The Role of Proximate Causation in Child Pornography Possession Cases Where Restitution Is Sought' [2011] Cardozo Law Review.[298].
} 
khusus dikaitkan dengan kerugian aktual yang dialami korban yang disebabkan oleh perbuatan pelaku. Oleh karenanya, di dalam restitusi terdapat hubungan kausalitas antara kejahatan dan kerugian yang dialami korban. ${ }^{21}$

Agar tujuan-tujuan restituti tersebut tercapai, Burt Galaway mengemukakan empat manfaat restitusi sebagai berikut: ${ }^{22}$

1. Restitusi sebagai suatu syarat dijatuhkannya pidana percobaan membolehkan pengadilan untuk mengelak dari menjatuhkan pidana yang berat;

2. Perintah restitusi membantu memperbaharui kehormatan diri pelaku dengan memintanya bertanggungjawab atas apa yang telah diperbuat;

3. Restitusi sebagai sanksi pidana dan alternatif pidana penjara lebih murah; dan

4. Restitusi mampu memberikan kepada korban pemenuhan materi dan kepuasan psikologis.

\section{Kelemahan Pengaturan Kompensasi dan Restitusi di Indonesia}

Dalam KUHP, ketentuan yang memuat perlindungan terhadap korban sebatas pada penentuan jenis dan bobot ancaman pidana dengan melihat pada kondisi korban, misalnya tindak pidana penganiayaan sebagaimana diatur dalam Pasal 351 KUHP. Penganiayaan biasa ancaman pidananya penjara paling lama dua tahun delapan bulan atau pidana denda paling banyak Rp. 4.500, jika perbuatan mengakibatkan luka-luka berat diancam dengan pidana penjara paling lama lima tahun, dan jika mengakibatkan mati diancam dengan pidana penjara paling lama tujuh tahun. Adapun bentuk perlindungan lain seperti pidana ganti kerugian yang sangat bermanfaat bagi korban tidak diakomodasi dalam KUHP. Kurang diperhatikannya korban dalam KUHP karena dalam hukum pidana posisi korban langsung (direct victim) diabstraksikan sebagai kepentingan publik (indirect victim), sehingga perlindungannya dikompensasikan dengan penjatuhan pidana terhadap pelakunya. Abstraksi kepentingan korban dalam hukum pidana tersebut tidak dapat dilepaskan dari pengertian tindak pidana menurut pandangan retributif yang merupakan pelanggaran terhadap hukum negara yang bersifat publik..$^{23}$

${ }^{21}$ ibid. [299-300].

${ }^{22}$ Linda F Frank.Op.Cit.[113].

${ }^{23}$ G Widiartana, 'Ide Keadilan Restoratif Pada Kebijakan Penanggulangan Kekerasan Dalam Rumah Tangga Dengan Hukum Pidana', Ringkasan Disertasi pada Program Doktor Ilmu Hukum (2011).[14]. 
Selain itu, definisi-definisi hukum pidana yang diungkapkan oleh para ahli juga luput dari perhatian terhadap korban,24 misalnya menurut W.L.G. Lemaire, hukum pidana terdiri atas norma-norma yang berupa keharusan-keharusan dan laranganlarangan dimana pelanggarnya diancam dengan hukuman berupa penderitaan yang bersifat khusus. Senada dengan itu, W.F.C.van Hattum mendefinisikan hukum pidana sebagai keseluruhan dari asas-asas dan aturan-aturan yang diikuti oleh suatu negara atau masyarakat hukum umum lainnya, berupa larangan dilakukannya tindakan-tindakan yang bersifat melanggar hukum dan pelanggarnya diancam dengan penderitaan bersifat khusus sebagai hukumannya. Pengaturan dalam UU No. 8 Tahun 1981 Tentang Hukum Acara Pidana (KUHAP) juga lebih didominasi pada aspek perlindungan terhadap pelaku tindak pidana. Dalam Bab I tentang Ketentuan Umum, Pasal 1 KUHAP yang terdiri dari 32 angka tidak ditemukan pengertian korban. Adapun Bab VI tentang Tersangka dan Terdakwa, Bab VII tentang Bantuan Hukum, Bab XII tentang Ganti Kerugian dan Rehabilitasi, dan Bab XIV tentang Penyidikan, berisi ketentuan-ketentuan yang menyangkut hak pelaku.

Sedikitnya pengaturan mengenai perlindungan korban dalam KUHAP adalah wajar karena latar belakang diberlakukannya adalah menyangkut perlunya perlindungan HAM bagi pelaku tindak pidana yang seringkali dilanggar oleh aparat penegak hukum. Dengan demikian, lahirnya KUHAP memiliki tujuan utama untuk meningkatkan perlindungan HAM bagi pelaku tindak pidana baik ketika menjadi tersangka ataupun terdakwa ketika berhadapan dengan aparat penegak hukum yang diberikan kewenangan tertentu. ${ }^{25}$ KUHAP hendak menempatkan pelaku dalam kedudukan yang bermartabat atau posisi his entity and dignity as human being yang harus diperlakukan sesuai nilai-nilai humanistik. ${ }^{26}$ Ketentuan mengenai hak korban dalam KUHAP bersifat sangat terbatas untuk beberapa hal saja, misalnya hak untuk melakukan tuntutan ganti kerugian yang diatur dalam Pasal 98. Jika suatu

${ }^{24}$ P.A.F. Lamintang, Dasar-Dasar Hukum Pidana Indonesia (PT Citra Aditya Bakti 2011).[1-3].

${ }^{25}$ Mahrus Ali,[et.,al.], 'Urgensi Dan Legalitas Pemberian Kesaksian Melalui Teleconference Dalam Persidangan Perkara Pidana', Laporan Penelitian Kerjasama LPSK dengan FH UII (2013).[64].

${ }^{26}$ Andi Sofyan dan Abd. Asis, Hukum Acara Pidana: Suatu Pengantar (Karisma Putra Utama 2014).[49]. 
perbuatan yang menjadi dasar dakwaan di dalam suatu pemeriksaan perkara pidana oleh pengadilan negeri menimbulkan kerugian bagi orang lain, maka hakim ketua sidang atas permintaan orang itu dapat menetapkan untuk menggabungkan perkara gugatan ganti kerugian kepada perkara pidana itu.

Dalam konteks restitusi, pemberian restitusi terhadap korban tindak pidana terdapat dalam Pasal 98 sampai dengan Pasal 101 yang mengatur kemungkinan penggabungan perkara ganti kerugian. Pasal 98 menyebutkan bahwa jika suatu perbuatan yang menjadi dasar dakwaan di dalam suatu pemeriksaan perkara pidana oleh pengadilan negeri menimbulkan kerugian bagi orang lain, maka hakim ketua sidang atas permintaan orang itu dapat menetapkan untuk menggabungkan perkara gugatan ganti kerugian kepada perkara pidana itu. Permintaan tersebut hanya dapat diajukan selambat-lambatnya sebelum penuntut umum mengajukan tuntutan pidana. Dalam hal penuntut umum tidak hadir, permintaan diajukan selambat-lambatnya sebelum hakim menjatuhkan putusan. Penggabungan perkara ganti kerugian sebagaimana diatur dalam KUHAP tersebut sesuai dengan asas keseimbangan yang tidak hanya mementingkan terhadap perlindungan hak pelaku namun juga perlindungan hak korban sebagai pihak lain yang terkait. Selain itu, tujuan penggabungan perkara ini adalah tercapainya asas peradilan yang sederhana, cepat, dan biaya murah. ${ }^{27}$ Dengan proses ini, korban bisa mengajukan gugatan ganti kerugian tanpa melalui gugatan perdata biasa dan tanpa menunggu selesainya proses perkara pidananya, sehingga korban diharapkan dapat segera mendapatkan ganti kerugian yang ditimbulkan akibat tindak pidana.

Meskipun sudah mencerminkan perlindungan terhadapkorban, namun ketentuan penggabungan perkara sebagaimana diatur dalam Pasal 98 sampai dengan Pasal 101 KUHAP ada kelemahannya. Beberapa kelemahannya antara lain: bergantung pada perkara pokoknya, ganti kerugian hanya atas kerugian materiil, pengajuannya paling lambat sebelum penuntutan, upaya hukumnya tergantung pada perkara pokok, dan apabila perkara pidananya tidak banding maka gugatan ganti kerugian juga tidak

${ }^{27}$ Yahya Harahap, Pembahasan Permasalahan Dan Penerapan KUHAP: Pemeriksaan Sidang Pengadilan, Banding, Kasasi, Dan Peninjauan Kembali (2rd edn, Sinar Grafika 2008).[8]. 
bisa banding. Dengan kelemahan-kelemahan tersebut, penggabungan perkara ganti kerugian menjadi tidak sepenuhnya berorientasi pada perlindungan terhadap korban, misalnya di tingkat pengadilan negeri seorang terdakwa diputus dengan pemidanaan, namun tuntutan ganti kerugiannya tidak dikabulkan.

Jika perkara pidananya tidak banding maka perkara ganti kerugiannya juga tidak bisa banding padahal bisa saja korban masih merasa berhak atas ganti kerugian. Contoh lain, jika korban ingin mendapatkan ganti kerugian penuh, maka tetap harus melalui proses pemeriksaan perdata karena penggabungan dalam perkara pidana hanya terbatas pada jumlah kerugian materiil yang dialaminya sebagaimana diatur dalam Pasal 99 ayat 2. Menurut Fauzy Marasabessy ketentuan Pasal 99 ayat 2 yang membatasi hanya pada kerugian materiil tersebut sesungguhnya kontradiksi dengan isi Pasal 101 yang berbunyi: "ketentuan dari aturan hukum acara perdata berlaku bagi gugatan ganti kerugian". ${ }^{28}$ Dengan demikian, seharusnya tidak perlu ada pembatasan terhadap jenis kerugian sebagaimana ketentuan yang berlaku pada hukum perdata sepanjang kerugian tersebut baik materiil maupun immateriil benar-benar sesuai dengan prinsip kausalitas sebagaimana diatur pada Pasal 1365 KUHPerdata.

Dalam Undang-Undang No. 26 Tahun 2000 Tentang Pengadilan Hak Asasi Manusia, ketentuan mengenai kompensasi dan restitusi diatur dalam Pasal 35, yaitu: pertama, setiap korban dan saksi dalam pelanggaran hak asasi manusia yang berat dan atau ahli warisnya dapat memperoleh kompensasi, restitusi, dan rehabilitasi. Kedua, kompensasi, restitusi, dan rehabilitasi sebagaimana dimaksud dalam ayat 1 dicantumkan dalam amar putusan Pengadilan HAM, dan ketiga ketentuan mengenai kompensasi, restitusi, dan rehabilitasi diatur lebih lanjut dengan Peraturan Pemerintah.

Ketentuan selanjutnya terkait dengan kompensasi dan restitusi dalam pelanggaran HAM yang berat diatur dalam Peraturan Pemerintah No. 3 Tahun 2002 Tentang Kompensasi, Restituti dan Rehabilitasi terhadap Korban Pelanggaran Hak Asasi Manusia yang Berat. Dalam Bab Ketentuan Umum,

\footnotetext{
${ }^{28}$ Fauzy Marasabessy, 'Restitusi Bagi Korban Tindak Pidana: Sebuah Tawaran Mekanisme Baru’ (2015) 45 Jurnal Hukum dan Pembangunan <http://jhp.ui.ac.id/index.php/home/article/viewFile/9/9>.[56].
} 
Pasal 1 huruf 4 dan 5 PP No. 3 Tahun 2002 dijelaskan bahwa kompensasi adalah ganti kerugian yang diberikan oleh negara karena pelaku tidak mampu memberikan ganti kerugian sepenuhnya yang menjadi tanggung jawabnya. Sementara restitusi adalah ganti kerugian yang diberikan kepada korban atau keluarganya oleh pelaku atau pihak ketiga, dapat berupa pengembalian harta milik, pembayaran ganti kerugian untuk kehilangan atau penderitaan, atau penggantian biaya untuk tindakan tertentu.

Kompensasi dan restitusi tersebut diberikan kepada korban atau keluarga korban yang merupakan ahli warisnya. Instansi Pemerintah terkait termasuk Departemen Keuangan yang secara tegas disebut dalam amar putusan bertugas melaksanakan pemberian kompensasi berdasarkan putusan Pengadilan HAM yang telah memperoleh kekuatan hukum tetap. Dalam hal kompensasi menyangkut pembiayaan dan perhitungan keuangan negara, pelaksanaannya dilakukan oleh Departemen Keuangan. Adapun pemberian restitusi dilaksanakan oleh pelaku atau pihak ketiga berdasarkan perintah yang tercantum dalam amar putusan Pengadilan HAM.

Tata cara pemberian kompensasi dan restitusi sebagaimana diatur dalam PP No. 3 Tahun 2002 adalah sebagai berikut:

1. Pengadilan HAM mengirimkan salinan putusan Pengadilan HAM, Pengadilan Tinggi, atau Mahkamah Agung, yang telah memperoleh kekuatan hukum tetap kepada Jaksa Agung.

2. Jaksa Agung melaksanakan putusan tersebut dengan membuat berita acara pelaksanaan putusan pengadilan kepada Instansi Pemerintah Terkait untuk melaksanakan pemberian kompensasi, dan kepada pelaku atau pihak ketiga untuk melaksanakan pemberian restitusi.

3. Instansi Pemerintah Terkait melaksanakan pemberian kompensasi serta pelaku atau pihak ketiga melaksanakan pemberian restitusi, paling lambat 30 hari kerja terhitung sejak berita acara diterima.

4. Pelaksanaan pemberian kompensasi atau restitusi dilaporkan oleh Instansi Pemerintah Terkait, pelaku, atau pihak ketiga kepada Ketua Pengadilan HAM yang memutus perkara, disertai dengan tanda bukti pelaksanaan pemberian kompensasi atau restitusi.

5. Salinan tanda bukti pelaksanaan pemberian kompensasi atau restitusi tersebut disampaikan kepada korban atau keluarga korban yang merupakan ahli warisnya.

6. Setelah menerima tanda bukti pelaksanaan pemberian kompensasi atau restitusi, Ketua Pengadilan HAM mengumumkan pelaksanaan tersebut pada papan 
pengumuman pengadilan yang bersangkutan.

7. Dalam hal pelaksanaan pemberian kompensasi atau restitusi kepada pihak korban melampaui batas waktu yang telah ditentukan, korban atau keluarga korban yang merupakan ahli warisnya dapat melaporkan hal tersebut kepada Jaksa Agung.

8. Jaksa Agung setelah menerima laporan segera memerintahkan Instansi Pemerintah Terkait, pelaku, atau pihak ketiga untuk melaksanakan putusan tersebut paling lambat tujuh hari kerja terhitung sejak tanggal perintah tersebut diterima.

9. Dalam hal pemberian kompensasi dan restitusi dapat dilakukan secara bertahap, maka setiap tahapan pelaksanaan atau kelambatan pelaksanaan harus dilaporkan kepada Jaksa Agung.

Terdapat kelemahan dalam pengaturan kompensasi dan restitusi dalam UU Pengadilan HAM, sehingga belum sepenuhnya berorientasi pada perlindungan korban tindak pidana. Kompensasi merupakan ganti kerugian yang diberikan oleh negara hanya jika pelaku tidak mampu membayar restitusi kepada korban. Restitusi sendiri akan dimasukkan dalam amar putusan pengadilan jika terdakwa diputus dengan pemidanaan. Dengan demikian kompensasi dan restitusi tidak dapat diberikan kepada korban jika tidak ada terdakwa yang diputus dengan pemidanaan dalam peristiwa pelanggaran HAM yang berat. Ketentuan ini dapat menghalangi korban untuk mendapatkan kompensasi padahal banyak korban yang nyata-nyata telah mengalami kerugian dalam peristiwa pelanggaran HAM yang berat terutama di masa lalu (sebelum diberlakukan UU Pengadilan HAM) tetapi sulit membuktikan pelakunya karena peristiwanya sudah sangat lama sehingga banyak alat bukti yang sudah tidak ada.

Seharusnya kompensasi tidak mendasarkan pada ketidakmampuan pelaku dalam membayar restitusi. Dalam perkara Tanjung Priok di Pengadilan HAM ad hoc terdakwa dinyatakan terbukti melakukan pelanggaran HAM yang berat, sehingga dalam amar putusannya mencantumkan restitusi. Namun di tingkat banding dan kasasi, terdakwa dibebaskan dan restitusi tidak dicantumkan kembali dalam amar putusan. Dalam perkara tersebut, sebenarnya pengadilan mengakui akan adanya peristiwa pelanggaran HAM yang berat namun pengadilan menilai tidak ada alat bukti yang menunjukkan bahwa terdakwa sebagai pelaku pelanggaran HAM yang berat. Dengan demikian, korban tidak mendapatkan ganti kerugian apapun 
padahal ia nyata-nyata telah mengalami kerugian dalam peristiwa pelanggaran HAM yang berat Tanjung Priok. ${ }^{29}$

Selain itu, dalam UU Pengadilan HAM juga tidak ditentukan indikator yang jelas untuk menentukan jumlah restitusi atau kompensasi yang dapat diberikan kepada korban. Pasal 2 ayat 2 PP No. 3 Tahun 2002 hanya menyebutkan bahwa pemberian kompensasi harus diberikan secara tepat, layak, dan cepat, sementara jumlahnya ditentukan oleh hakim. Hal ini sesuai dengan Penjelasan Umum PP No. 3 Tahun 2002 yang berbunyi:

"Ganti kerugian atau pengembalian hak, misalnya pengembalian kebutuhan dasar yang meliputi kebutuhan fisik dan kebutuhan non fisik, yang masuk dalam lingkup kompensasi, restitusi dan rehabilitasi diputus oleh Pengadilan HAM di setiap tingkatan pengadilan. Mengenai besarnya ganti kerugian atau pemulihan kebutuhan dasar tersebut diserahkan sepenuhnya kepada hakim yang memutus perkara yang dicantumkan dalam amar putusannya. Jadi, hakim diberikan kebebasan sepenuhnya secara adil, layak, dan cepat mengenai besarnya ganti kerugian tersebut berdasarkan hasil penyelidikan, penyidikan, dan penuntutan, serta pemeriksaan di sidang pengadilan beserta bukti-bukti yang mendukungnya”.

Kata "cepat" dalam penjelasan Pasal 2 ayat 2 disebutkan bahwa penggantian kerugian dan atau pemulihan hak-hak lainnya diberikan kepada korban sesegera mungkin dalam rangka secepatnya mengurangi penderitaan korban. Ketentuan ini dalam praktiknya akan sulit terealisasi karena dalam Pasal 3 disebutkan bahwa Instansi Pemerintah Terkait bertugas melaksanakan pemberian kompensasi dan rehabilitasi berdasarkan putusan Pengadilan HAM yang telah memperoleh kekuatan hukum tetap. Dalam catatan Institute for Criminal Justice Reform, pengalaman penyidikan hingga putusan berkekuatan hukum tetap pada Pengadilan HAM ad hoc memerlukan waktu bertahun-tahun. ${ }^{30}$

Dalam Undang-Undang No. 15 Tahun 2003 Tentang Pemberantasan Tindak Pidana Terorisme, pemberian kompensasi dan restitusi secara khusus diatur dalam Bab IV tentang Kompensasi, Restitusi, dan Rehabilitasi yang terdiri dari Pasal 36

\footnotetext{
${ }^{29}$ Supriyadi Widodo dan Zainal Abidin, Memastikan Pemenuhan Hak Atas Reparasi Korban Pelanggaran HAM Yang Berat (Institute for Criminal Justice Reform 2014).[14].

${ }^{30}$ ibid.[15].
} 
sampai dengan Pasal 42. Pasal 36 Undang-Undang No. 15 Tahun 2003 berbunyi: ayat pertama, setiap korban atau ahli warisnya akibat tindak pidana terorisme berhak mendapatkan kompensasi atau restitusi. Kedua, kompensasi sebagaimana dimaksud dalam ayat 1 , pembiayaannya dibebankan kepada negara yang dilaksanakan oleh Pemerintah. Ketiga, restitusi sebagaimana dimaksud dalam ayat 1, merupakan ganti kerugian yang diberikan oleh pelaku kepada korban atau ahli warisnya. Keempat, kompensasi dan/atau restitusi tersebut diberikan dan dicantumkan sekaligus dalam amar putusan pengadilan.

Dalam Pasal 38 diatur bahwa pengajuan kompensasi dilakukan oleh korban atau kuasanya kepada Menteri Keuangan berdasarkan amar putusan pengadilan negeri. Sementara pengajuan restitusi dilakukan oleh korban atau kuasanya kepada pelaku atau pihak ketiga berdasarkan amar putusan pengadilan. Menteri Keuangan memberikan kompensasi dan pelaku memberikan restitusi, paling lambat 60 hari kerja terhitung sejak penerimaan permohonan. Pelaksanaan pemberian kompensasi atau restitusi dilaporkan oleh Menteri Keuangan, pelaku, atau pihak ketiga kepada Ketua Pengadilan yang memutus perkara disertai dengan tanda bukti pelaksanaan pemberian kompensasi dan restitusi. Salinan tanda bukti pelaksanaan pemberian kompensasi dan restitusi tersebut selanjutnya disampaikan kepada korban atau ahli warisnya. Setelah menerima tanda bukti, Ketua Pengadilan mengumumkan pelaksanaan tersebut pada papan pengumuman pengadilan yang bersangkutan.

Dalam hal pelaksanaan pemberian kompensasi dan restitusi kepada pihak korban melampaui batas waktu yang telah ditentukan, korban atau ahli warisnya dapat melaporkan hal tersebut kepada pengadilan. Pengadilan kemudian segera memerintahkan Menteri Keuangan, pelaku, atau pihak ketiga untuk melaksanakan putusan tersebut paling lambat 30 hari kerja terhitung sejak tanggal perintah tersebut diterima. Adapun dalam hal pemberian kompensasi atau restitusi dapat dilakukan secara bertahap, maka setiap tahapan pelaksanaan atau keterlambatan pelaksanaan dilaporkan kepada pengadilan.

Terdapat kelemahan dalam ketentuan pemberian kompensasi dan restitusi di 
atas. Salah satunya adalah ketergantungan kompensasi dan restutisi dengan putusan perkara pidananya. Jika terdakwa tidak diputus dengan pemidanaan, kompensasi dan restitusi tidak dapat diberikan. Ketentuan ini kurang mencerminkan orientasi perlindungan terhadap korban karena meskipun nyata-nyata terjadi peristiwa tindak pidana terorisme dan korban mengalami kerugian, kompensasi dan restitusi tidak akan diberikan jika tidak ada terdakwa yang diputus dengan pemidanaan. Seharusnya kompensasi tidak digantungkan pada perkara pidananya, akan tetapi tetap dapat diberikan sepanjang dalam faktanya terjadi peristiwa tindak pidana terorisme dan korban nyata mengalami kerugian akibat peristiwa tersebut. Mekanisme yang mengharuskan korban atau ahli warisnya mengajukan permohonan kompensasi kepada Menteri Keuangan dan permohonan restitusi kepada pelaku atau ahli warisnya juga menjadi kendala dalam pemenuhan kompensasi dan restitusi secara cepat karena proses ini dapat mencipakan birokrasi yang panjang. Seharusnya tidak perlu ada permohonan dari korban atau ahli warisnya, cukup pengadilan memerintahkan melalui pencantuman dalam amar putusannya.

Undang-Undang No. 21 Tahun 2007 Tentang Pemberantasan Tindak Pidana Perdagangan Orang tidak mengatur mengenai kompensasi, namun hanya mengatur mengenai restitusi. Dalam Pasal 1 angka 13, restitusi didefinisikan sebagai pembayaran ganti kerugian yang dibebankan kepada pelaku berdasarkan putusan pengadilan yang berkekuatan hukum tetap atas kerugian materiil dan/atau immateriil yang diderita korban atau ahli warisnya. Ketentuan mengenai restitusi diatur dalam Pasal 48 sampai dengan Pasal 50. Pada Pasal 48 mengatur tentang:

(1) Setiap korban tindak pidana perdagangan orang atau ahli warisnya berhak memperoleh restitusi.

(2) Restitusi sebagaimana dimaksud pada ayat 1 berupa ganti kerugian atas:

a. kehilangan kekayaan atau penghasilan;

b. penderitaan;

c. biaya untuk tindakan perawatan medis dan/atau psikologis; dan/atau

d. kerugian lain yang diderita korban sebagai akibat perdagangan orang.

(3) Restitusi tersebut diberikan dan dicantumkan sekaligus dalam amar putusan pengadilan tentang perkara tindak pidana perdagangan orang.

(4) Pemberian restitusi sebagaimana dimaksud pada ayat 1 dilaksanakan sejak dijatuhkan putusan pengadilan tingkat pertama.

(5) Restitusi sebagaimana dimaksud pada ayat 4 dapat dititipkan terlebih dahulu di 
pengadilan tempat perkara diputus.

(6) Pemberian restitusi dilakukan dalam 14 hari terhitung sejak diberitahukannya putusan yang telah memperoleh kekuatan hukum tetap.

(7) Dalam hal pelaku diputus bebas oleh pengadilan tingkat banding atau kasasi, maka hakim memerintahkan dalam putusannya agar uang restitusi yang dititipkan dikembalikan kepada yang bersangkutan.

Menurut UU No. 21/2007, pelaksanaan pemberian restitusi dilaporkan kepada ketua pengadilan yang memutuskan perkara, disertai dengan tanda bukti pelaksanaan pemberian restitusi tersebut. Setelah ketua pengadilan menerima tanda bukti tersebut, ketua pengadilan mengumumkan pelaksanaan pemberian restitusi di papan pengumuman pengadilan yang bersangkutan. Salinan tanda bukti pelaksanaan pemberian restitusi disampaikan oleh pengadilan kepada korban atau ahli warisnya. Dalam hal pelaksanaan pemberian restitusi kepada pihak korban tidak dipenuhi sampai melampaui batas waktu yang ditentukan, korban atau ahli warisnya memberitahukan hal tersebut kepada pengadilan. Pengadilan selanjutnya memberikan surat peringatan secara tertulis kepada pemberi restitusi untuk segera memenuhi kewajiban memberikan restitusi kepada korban atau ahli warisnya. Dalam hal surat peringatan tersebut tidak dilaksanakan dalam waktu 14 hari, pengadilan memerintahkan penuntut umum untuk menyita harta kekayaan terpidana dan melelang harta tersebut untuk pembayaran restitusi. Jika pelaku tidak mampu membayar restitusi, maka pelaku dikenai pidana kurungan pengganti paling lama satu tahun.

Berdasarkan pengaturan di atas, ada kelemahan terkait dengan pemberian restitusi terhadap korban tindak pidana perdagangan orang, yaitu: pertama, pemberian restitusi tergantung dari putusan perkara pidananya. Apabila terdakwa diputus bebas oleh pengadilan, maka korban tidak akan mendapatkan ganti kerugian apapun. Meskipun dalam faktanya seseorang mengalami kerugian baik materiil maupun immateriil karena menjadi korban tindak pidana perdagangan orang, ia tidak akan mendapatkan ganti kerugian jika terdakwa diputus bebas. Kedua, apabila pelaku tidak melaksanakan putusan pengadilan untuk memberikan restitusi dan juga tidak memiliki harta kekayaan cukup, maka korban tidak akan mendapatkan ganti kerugian apapun karena pelaku hanya akan dikenai pidana kurungan pengganti paling lama satu tahun. Dengan demikian, pengaturan restitusi dalam UU No. 21/2007 belum 
sepenuhnya berorientasi pada perlindungan terhadap korban tindak pidana.

Definisi kompensasi dan restitusi dalam Undang-Undang No. 13 Tahun 2006 jo Undang-Undang No. 31 Tahun 2014 Tentang Perlindungan Saksi dan Korban diatur dalam Pasal 1 angka 10 dan 11. Kompensasi didefinisikan sebagai ganti kerugian yang diberikan oleh negara karena pelaku tidak mampu memberikan ganti kerugian sepenuhnya yang menjadi tanggung jawabnya kepada Korban atau Keluarganya. Sedangkan restitusi adalah ganti kerugian yang diberikan kepada Korban atau Keluarganya oleh pelaku atau pihak ketiga. Pengaturan mengenai kompensasi terdapat dalam Pasal 7 yang berbunyi:

(1) Setiap Korban pelanggaran hak asasi manusia yang berat dan Korban tindak pidana terorisme selain mendapatkan hak sebagaimana dimaksud dalam Pasal 5 dan 6, juga berhak atas Kompensasi.

(2) Kompensasi bagi Korban pelanggaran hak asasi manusia yang berat diajukan oleh oleh Korban, Keluarga, atau kuasanya kepada Pengadilan Hak Asasi Manusia melalui LPSK.

(3) Pelaksanaan pembayaran Kompensasi sebagaimana dimaksud pada ayat 2 diberikan oleh LPSK berdasarkan putusan pengadilan yang telah memperoleh kekuatan hukum tetap.

(4) Pemberian Kompensasi bagi Korban tindak pidana terorisme dilaksanakan sesuai dengan ketentuan Undang-Undang yang mengatur mengenai pemberantasan tindak pidana terorisme.

Adapun terkait dengan restitusi diatur dalam Pasal 7A yang berbunyi:

(1) Korban tindak pidana berhak memperoleh Restitusi berupa:

a. ganti kerugian atas kehilangan kekayaan atau penghasilan;

b. ganti kerugian yang ditimbulkan akibat penderitaan yang berkaitan langsung sebagai akibat tindak pidana; dan/atau

c. penggantian biaya perawatan medis dan/atau psikologis.

(2) Tindak pidana sebagaimana dimaksud pada ayat 1 ditetapkan dengan Keputusan LPSK.

(3) Pengajuan permohonan Restitusi dapat dilakukan sebelum atau setelah putusan pengadilan yang telah memperoleh kekuatan hukum tetap melalui LPSK.

(4) Dalam hal permohonan Restitusi diajukan sebelum putusan pengadilan yang telah memperoleh kekuatan hukum tetap, LPSK dapat mengajukan Restitusi kepada penuntut umum untuk dimuat dalam tuntutannya.

(5) Dalam hal permohonan Restitusi diajukan setelah putusan pengadilan yang telah memperoleh kekuatan hukum tetap, LPSK dapat mengajukan Restitusi kepada pengadilan untuk mendapat penetapan.

(6) Dalam hal Korban tindak pidana meninggal dunia, Restitusi diberikan kepada Keluarga Korban yang merupakan ahli waris Korban. 
Tata cara pemberian kompensasi dan restitusi lebih lanjut diatur dalam Peraturan Pemerintah No. 44 Tahun 2008 Tentang Pemberian Kompensasi, Restitusi dan Bantuan Kepada Saksi dan Korban. PP ini belum berubah meskipun UU No. 13 Tahun 2006 telah diubah dengan UU No. 31 Tahun 2014. Berdasarkan PP No. 44 tahun 2008, permohonan untuk memperoleh restitusi diajukan oleh korban, keluarga, atau kuasanya dengan surat kuasa khusus secara tertulis kepada pengadilan melalui LPSK. Dalam PP juga diatur mengenai ketentuan waktu pengajuan permohonan restitusi, persyaratan administratif, jangka waktu pelaksanaan, serta beberapa hal teknis lainnya.

Karena hanya diatur dalam level PP, hakim dan jaksa lebih memilih menggunakan penggabungan perkara sebagaimana diatur dalam Pasal 98 sampai dengan Pasal 101 KUHAP. Hakim dan jaksa menganggap PP tidak selevel dengan KUHAP dan tidak bisa mengatur hukum acara. Dampaknya, korban hanya dapat memperoleh ganti kerugian yang sangat terbatas, yaitu kerugian yang bersifat nyata atau materiil saja. Oleh sebab itu kemudian lahirlah UU No. 31 Tahun 2014 yang mengakomodasi beberapa mekanisme pemberian restitusi yang sebelumnya diatur dalam PP No. 44 tahun 2008.

Meskipun keberadaan UU No. 31 Tahun 2014 dapat "memaksa" hakim dan jaksa untuk menggunakan UU PSK bukan KUHAP lagi, namun beberapa pengaturan dalam UU PSK masih memiliki kelemahan. Dimasukkannya Pasal 7A ayat 2 dalam UU No. 31 Tahun 2014 justru membatasi pemberian restitusi hanya untuk korban tindak pidana tertentu saja. Pasal 7A ayat 2 tersebut berbunyi: "Tindak pidana sebagaimana dimaksud pada ayat 1 ditetapkan dengan Keputusan LPSK”. Berdasarkan bunyi pasal tersebut, tidak semua korban yang mengalami kerugian akibat tindak pidana dapat mendapatkan restitusi karena akan dibatasi untuk korban tindak pidana tertentu saja berdasarkan Keputusan LPSK. Selain itu, UU PSK juga tidak menentukan kriteria yang bisa menjadi pedoman bagi LPSK untuk memutuskan jenis tindak pidana apa yang korbannya dapat diberikan restitusi.

Kelemahan lain dari UU PSK adalah mengenai tidak ada batasan kapan hakim harus menetapkan permohonan restitusi yang diajukan setelah ada putusan pengadilan 
yang telah memperoleh kekuatan hukum tetap. Selain itu, tidak ada "alat pemaksa" bagi pelaku untuk membayar restitusi yang ditetapkan oleh pengadilan baik karena keengganan pelaku atau pelaku memang tidak mampu membayarnya. Penggantian restitusi dengan kompensasi juga tidak mungkin karena pemberian kompensasi dalam UU PSK dibatasi hanya untuk korban pelanggaran HAM yang berat dan korban tindak pidana terorisme, tidak untuk tindak pidana selain keduanya. Dari kelemahankelemahan tersebut, pengaturan kompensasi dan restitusi dalam UU PSK belum sepenuhnya berorientasi pada perlindungan terhadap korban tindak pidana.

\section{Gagasan Pembaharuan Pengaturan Kompensasi dan Restitusi di Indonesia}

Pengaturan kompensasi dalam perundang-undangan di Indonesia masih belum berorientasi kepada perlindungan terhadap korban. Beberapa kelemahan yang ada seperti pemberian kompensasi bergantung kepada putusan pengadilan terhadap terdakwa dan baru diberikan setelah putusan berkekuatan hukum tetap, mencerminakan bahwa pengaturan kompensasi masih berparadigma hukum pidana. Hal ini tampak pada penyamaan mekanisme antara kompensasi dan restitusi meskipun kedua hak korban tersebut memiliki perbedaan landasan filosofis dan karakteristik.

Secara filosofis pemberian kompensasi oleh negara kepada korban merupakan bukti bahwa negara gagal melindungi dan memberikan rasa aman kepada korban. Aparat penegak hukum yang merupakan representasi dari negara gagal mencegah terjadinya suatu tindak pidana sehingga menimbulkan kerugian kepada korban. ${ }^{31}$ Konsekuensinya, negara dituntut untuk memberikan ganti rugi kepada korban sebagai bentuk kegagalan dan pertanggungjawabannya kepada warga negara (korban). Sedangkan restitusi merupakan implikasi dari pergeseran paradigma pemidanaan; dari yang berorientasi kepada pembalasan (retributive justice) ke yang berorientasi pemulihan (restorative justice). Restitusi merupakan salah satu upaya untuk memenuhi kepentingan dan kebutuhan korban yang selama ini dilupakan dalam sistem peradilan pidana. ${ }^{32}$ Restitusi sebenarnya merupakan bagian kecil dari

\footnotetext{
${ }^{31}$ Nicholas C Katsoris.Op.Cit.[189].

${ }^{32}$ Marcus A Asner.[et.,al.]Op.Cit.[59].
} 
upaya untuk memenuhi hak-hak korban. Melalui restitusi pelaku kejahatan dimintai pertanggungjawaban atas kerugian yang dialami korban.

Perbedaan filosofis kompensasi dan karakteristik kompensasi dan restitusi tersebut harus dijadikan sebagai basis dalam pembaharuan pengaturan kompensasi dan restitusi dalam perundang-undangan di Indonesia. Dalam konteks inilah paradigma kompensasi di satu sisi harus mengacu pemenuhan hak-hak warga negara dan pada sisi yang lain sebagai bentuk dan pengakuan "bersalah" negara karena gagal melindungi dan memberikan rasa aman kepada tiap-tiap warga negara. Dengan kata lain, pengaturan kompensasi perlu dikaitkan dengan pelanggaran hak asasi manusia yang selalu melibatkan aktor negara. Paradigma yang demikian akan berimplikasi kepada pembaharuan pengaturan kompensasi yang rinciannya sebagai berikut.

Pemberian kompensasi oleh negara tidak perlu bergantung kepada putusan pengadilan terhadap terdakwa karena tidak ada kaitan antara kompensasi tersebut dengan pernyataan kesalahan terdakwa yang dituangkan dalam putusan pengadilan. Jika kompensasi pada dasarnya merupakan bentuk kegagalan negara untuk melindungi dan memberikan rasa aman kepada korban, maka ia diberikan kepada tiap-tiap warga negara yang menjadi korban kejahatan. Negara berkewajiban untuk memberikan kompensasi kepada tiap-tiap warga negara yang menjadi korban suatu tindak pidana. Konsekuensinya, cakupan tindak pidana di mana korban berhak mendapatkan kompensas dari negara yang dibatasi hanya pada genosida, kejahatan terhadap kemanusiaan, dan tindak pidana terorisme tidak perlu dipertahankan lagi.

Apabila kompensasi tidak perlu bergantung kepada putusan pengadilan terhadap terdakwa, maka kompensasi diberikan juga kepada korban suatu tindak pidana yang pelakunya meninggal dunia sebelum proses peradilan selesai atau digelar. Dalam perkara tindak pidaan terorisme, pelaku kadangkala meninggal dunia sebelum proses peradilan terhadapnya digelar atau selesai dilakukan sampai pada putusan pengadilan yang berkekuatan hukum tetap. Kompensasi juga diberikan kepada korban salah tangkap aparat penegak hukum. Sebagai bentuk tanggung jawab negara dan agar aparat penegak hukum berhati-hati ketika menangkap atau menetapkan seseorang sebagai tersangka, negara seharusnya memberikan kompensasi kepada warga negara 
yang menjadi korban salah tangkap aparat penegak hukum. Negara telah melanggar hak atas rasa aman atau hak untuk bebas dari penyiksaan warga negara, dan oleh karenanya, negara wajib memberikan kompensasi kepadanya.

Biaya-biaya apa yang harus ditanggung oleh negara dan diberikan kepada korban? Jawaban atas pertanyaan ini bergantung kepada kemampuan dan ketersediaan dana oleh negara. Idealnya, kompensasi yang diberikan kepada korban meliputi kerugian materiil dan immateriil berobat, konseling kesehatan mental, biaya pemakaman, kehilangan gaji, biaya pembelian kacamata, lensa kontak, perawatan gigi, pembelian alat-alat prostetik, biaya berpindah atau relokasi, biaya transportasi untuk memperoleh perawatan medis, rehabilitasi pekerjaan, layanan pengganti bagi perawatan bayi/anak-anak, dan bantuan domestik. ${ }^{33}$ Tapi jika biaya-biaya tersebut tidak mampu dibayarkan semuanya oleh negara, paling tidak negara memberikan kompensasi berupa kerugian yang secara langsung dialami korban akibat suatu tindak pidana. Untuk korban yang mengalami trauma atau stres, negara harus menanggung semua biaya agar korban dapat pulih kembali. Dalam hal negara tidak mampu memberikan kompensasi sekaligus kepada korban, negara dapat membayarnya tiap bulan atau tiap tahun. Jika hal itu sulit dilakukan, kompensasi dapat dikonversi ke dalam bentuk pengurangan pajak, potongan biaya tertentu yang seharusnya dibayar oleh korban, pemberian fasilitas pendidikan atau kesehatan tertentu, untuk memastikan bahwa program kompensasi berjalan lancar dan hak-hak korban dipenuhi, negara perlu membentuk skema kompensasi yang disubsidi atau didanai oleh negara yang disebut dengan dana publik. Dana yang dikumpulkan dapat berasal beberapa sumber, antara lain denda, hasil penyitaan aset terpidana, sebagian penerimaan pajak, atau sumbangan dari perorangan atau lembaga swasta yang tidak mengikat, ${ }^{34}$ dan diberikan atas kebutuhan-kebutuhan

\footnotetext{
${ }^{33}$ Lieutenant Colonel Warren G Foote.Op.Cit.[51].

${ }^{34}$ Working Group on Trafficking in Persons, Compensation of Victims of Trafficking in Persons National Approaches to Compensation of Victims of Trafficking in Persons (Working Group on Trafficking in Persons 2010) <https:/www.unodc.org/documents/treaties/organized_crime/COP5/ CTOC_COP_WG4_2010_CRP1/CTOC_COP_WG4_2010_CRP1_E.pdf $>$.[3].
} 
khusus korban. ${ }^{35}$ Dana tersebut dikelola oleh lembaga tertentu (LPSK) dengan kewajiban untuk melaporkannya kepada publik dan adanya audit oleh auditor independen tiap tahunnya.

Prosedur permohonan kompensasi juga masih mencerminkan birokrasi yang panjang dan rumit. Prosedur ini seharusnya dibuat sederhana. Sebagai contoh, dibuat satu pintu permohonan kompensasi secara online ataupun off line dengan memberikan tugas tambahan kepada LPSK. Untuk urusan koordinasi dengan instansi atau kementrian terkait, biarlah LPSK yang mengurusnya, dan tidak perlu dibebankan kepada pemohon (korban).

Dalam konteks restitusi, pembaharuan pengaturan restitusi perlu mengacu kepada paradigma keadilan restoratif dengan menfokuskan pada tanggung jawab pelaku untuk memberikan ganti rugi kepada korban atas tindak pidana yang dilakukan di satu sisi dan kesediaan korban untuk memaafkan kesalahan pelaku pada sisi yang lain. ${ }^{36}$ Dengan kata lain, sebelum restitusi dibayarkan oleh pelaku kepada korban, keduanya perlu bertemu dengan tujuan untuk memperbaiki kerusakan atau kerugian yang dialami korban. ${ }^{37}$

Pada konteks ini, ketentuan mengenai keharusan adanya ketergantungan pembayaran restitusi kepada putusan bersalah terhadap terdakwa yang telah berkekuatan hukum tetap yang terdapat dalam pelbagai peraturan perundangundangan menunjukkan bahwa ide dasar keadilan restoratif belum sebelumnya diintrodusir. Ketentuan tersebut seharusnya tidak berlaku mutlak, dalam arti putusan pengadilan yang berkekuatan hukum tetap tidak harus menjadi syarat mutlak bagi pembayaran restitusi oleh pelaku kepada korban. Ketentuan tersebut seharusnya baru diberlakukan apabila pelaku tidak mengakui kesalahannya dan tidak mau bertanggungjawab untuk memberikan restitusi kepada korban tanpa adanya putusan pengadilan yang telah berkekuatan hukum tetap.

\footnotetext{
${ }^{35}$ Frédéric Mégret.Op.Cit.[130-131].

${ }^{36}$ Gabriel H Teninbaum, 'Easing The Burden: Mediating Misdemeanor Criminal Matters' (2007) 62 Dispute Resolution Journal.[64].

${ }^{37}$ Mary Ellen Reimund, 'Mediation in Criminal Justice: A Restorative Approach' (2003) 46 Advocate.[22].
} 
Dalam hal pelaku mengakui kesalahannya dan bersedia memberikan restitusi kepada korban sebelum proses peradilan berlangsung atau sebelum putusan pengadilan berkekuatan hukum tetap, pelaku tetap dapat memberikan restitusi korban. Pemberian restitusi seperti ini dapat dijadikan sebagai hal yang meringankan pidana atau bahkan dapat dijadikan sebagai dasar bagi hakim untuk memaafkan pelaku (judicial pardon). Untuk kejahatan-kejahatan tertentu seperti kecelakaan lalu lintas di jalan raya yang menimbulkan korban luka-luka atau meninggal dunia, hakim dapat saja menyatakan terdakwa bersalah melakukan suatu tindak pidana, tapi tidak menjatuhkan pidana terhadapnya dengan alasan terdakwa telah membayar restitusi kepada korban dan telah ada perdamaian antara keduanya. ${ }^{38}$

Inisiatif permohonan restitusi tidak hanya datang dari korban, melainkan dari hakim dan penuntut umum. Hakim dan penuntut umum justru memiliki peran yang sangat strategis agar terdakwa bersedia membayar restitusi. Sekalipun korban tidak menuntut restitusi, hakim dan penuntut umum dapat saja meminta kesediaan terdakwa untuk membayarkannya kepada korban. Selain itu, dengan mengacu kepada konsep keadilan restoratif, terdakwa berkewajiban secara moral untuk memberikan ganti rugi kepada korban. Tujuan utamanya adalah agar hubungan baik antara korban dan terdakwa yang rusak akibat tindak pidana oleh terdakwa dapat dipulihkan kembali. Tujuan utama restitusi bukan pada pembalasan, melainkan pada penyembuhan dan perdamaian. Restitusi, dengan demikian, mengubah sistem peradilan pidana yang dikenal statis ke arah hukum pidana yang humanistis. ${ }^{39}$

Dalam hal pelaku tidak memiliki harta yang cukup untuk membayar restitusi kepada korban, penggantian dengan pidana kurungan paling lama 1 (satu) tahun menunjukkan bahwa ketentuan tersebut masih berparadigma retributive justice. Ketentuan tersebut perlu diperbaharui misalnya dengan ketentuan merampas aset pelaku dan diberikan kepada korban sesuai dengan jumlah restitusi yang diputuskan oleh pengadilan. Perampasan aset

${ }^{38}$ Chairul Huda, Dari Tiada Pidana Tanpa Kesalahan Menuju Tiada Pertanggungjawaban Pidana Tanpa Kesalahan (Kencana 2006).[75].

${ }^{39}$ Jack B Weinstein, 'Some Benefit and Risks of Privatization of Justice Though ADR' [1996] Ohio State Journal on Dispute Resolution.[292]. 
ini juga berlaku bagi pelaku yang meninggal dunia sebelum sempat membayarkan restitusi kepada korban pasca putusan pengadilan yang telah berkekuatan hukum tetap. Selain itu, dalam hal pelaku tidak memiliki cukup harta untuk membayar restitusi kepada korban, pelaku dapat saja diwajibkan mencarikan korban pekerjaan baru dalam hal diberhentikan dari pekerjaannya karena menjadi korban suatu tindak pidana, atau pelaku bekerja kepada korban selama waktu tertentu tanpa dibayar. Pekerjaan pelaku tersebut merupakan restitusi karena dia sendiri tidak memiliki cukup harta untuk dibayarkan kepada korban. Dengan demikian, makna restitusi tidak hanya dibatasi pada uang, tapi diperluas pada pekerjaan atau hal-hal lain yang bermanfaat secara langsung bagi korban.

Pembayaran restitusi oleh pelaku kepada korban juga harus dibatasi waktunya. Sebagai contoh, satu bulan pasca putusan pengadilan berkekuatan hukum tetap pelaku diwajibkan membayar sekaligus restitusi kepada korban, dan apabila melebihi jangka waktu tersebut aset pelaku disita. Tapi bila pelaku ternyata tidak memiliki harta yang cukup untuk membayar restitusi sekaligus kepada korban, putusan pengadilan dapat saja memerintahkan pelaku untuk membayar restitusi kepada korban dengan cara mencicil selama waktu tertentu. Ketentuan mengenai hal ini jika pelaku telah membuktikan di depan pengadilan bahwa dia benar-benar tidak memiliki harta yang cukup untuk membayar restitusi sekaligus kepada korban.

Cakupan tindak pidana yang mewajibkan pelaku membayar restitusi kepada korban juga diperluas untuk semua jenis tindak pidana sepanjang korban mengalami kerugian yang langsung disebabkan oleh tindak pidana pelaku. Restitusi harus diberlakukan kepada semua tindak pidana yang menimbulkan kerugian langung bagi korban. Hal ini karena tujuan utama keadilan restoratif adalah pada pemulihan dan perdamaian antara pelaku dan korban. Jumlah dan besaran restitusi yang dibayarkan pelaku kepada korban sesuai dengan putusan pengadilan dengan mengacu kepada bukti-bukti yang dihadirkan korban atau sesuai kesepakatan antara pelaku dan korban. 


\section{Kesimpulan}

Pengaturan kompensasi dan restitusi di Indonesia belum sepenuhnya berorientasi pada perlindungan terhadap korban tindak pidana karena terdapat kelemahan dalam pengaturannya. Dalam KUHAP, pengaturan penggabungan gugatan ganti kerugian dengan perkara pidana terbatas hanya berupa ganti kerugian yang bersifat materiil dan upaya hukumnya tergantung pada perkara pidananya. Dalam perundang-undangan di luar KUHP, pemberian kompensasi dan restitusi tergantung kepada putusan pengadilan terhadap terdakwa. Apabila pelaku tidak melaksanakan putusan pengadilan untuk memberikan restitusi dan juga tidak memiliki harta kekayaan cukup, maka korban tidak akan mendapatkan ganti kerugian apapun karena pelaku hanya akan dikenai pidana kurungan pengganti paling lama satu tahun. Selain itu, tidak ada batasan waktu bagi pengadilan untuk mengeluarkan penetapan terhadap permohonan restitusi yang diajukan setelah ada putusan pengadilan yang berkekuatan hukum tetap.

Pembaharuan pengaturan kompensasi memfokuskan pada pemenuhan hak-hak korban yang dilanggar oleh negara. Ia tidak perlu bergantung kepada putusan pengadilan terhadap terdakwa, diberikan juga kepada korban suatu tindak pidana yang pelakunya meninggal dunia sebelum proses peradilan selesai atau digelar, atau korban salah tangkap aparat penegak hukum. Kompensasi hanya pada kerugian materiil dan biaya pemulihan trauma atau stres, dan bisa dibayar langsung, dibayar tiap bulan atau tiap tahun, dan dapat dikonversi ke dalam bentuk lain. Restitusi berbasis kepada paradigma restorative justice. Ketentuan mengenai keharusan adanya putusan pengadilan yang berkekuatan hukum tetap baru dilaksanakan jika pelaku tidak mau membayar restitusi. Restitusi dapat dibayar oleh pelaku sebelum adanya putusan pengadilan dan dapat dijadikan sebagia hal yang meringankan pidana atau pemaafan hakim. Restitusi diberlakukan untuk semua tindak pidana yang menimbulkan kerugian korban secara langsung dan bentuknya tidak harus uang, serta pembayarannya bisa dicicil sesuai dengan kemampuan pelaku.

\section{Daftar Bacaan}

\section{Buku}

Andi Sofyan dan Abd. Asis, Hukum Acara Pidana: Suatu Pengantar (Karisma Putra 
Utama 2014).

Angkasa, 'Kedudukan Korban Dana Sistem Peradilan Pidana', Pelatihan Viktimologi Indonesia (Universitas Jenderal Soedirman 2016).

Chairul Huda, Dari Tiada Pidana Tanpa Kesalahan Menuju Tiada Pertanggungjawaban Pidana Tanpa Kesalahan (Kencana 2006).

G Widiartana, 'Ide Keadilan Restoratif Pada Kebijakan Penanggulangan Kekerasan Dalam Rumah Tangga Dengan Hukum Pidana', Ringkasan Disertasi pada Program Doktor Ilmu Hukum (2011).

Mahrus Ali,[et.,al.], 'Urgensi Dan Legalitas Pemberian Kesaksian Melalui Teleconference Dalam Persidangan Perkara Pidana', Laporan Penelitian Kerjasama LPSK dengan FH UII (2013).

P.A.F. Lamintang, Dasar-Dasar Hukum Pidana Indonesia (PT Citra Aditya Bakti 2011.

Supriyadi Widodo dan Zainal Abidin, Memastikan Pemenuhan Hak Atas Reparasi Korban Pelanggaran HAM Yang Berat (Institute for Criminal Justice Reform 2014).

Working Group on Trafficking in Persons, Compensation of Victims of Trafficking in Persons National Approaches to Compensation of Victims of Trafficking in Persons (Working Group on Trafficking in Persons 2010) <https:// www.unodc.org/documents/treaties/organized_crime/COP5/CTOC_COP WG4_2010_CRP1/CTOC_COP_WG4_2010_CRP1_E.pdf $>$.

Yahya Harahap, Pembahasan Permasalahan Dan Penerapan KUHAP: Pemeriksaan Sidang Pengadilan, Banding, Kasasi, Dan Peninjauan Kembali (2rd edn, Sinar Grafika 2008).

\section{Jurnal}

Benedict J Monachino, ' 'Enhancing Victims' Rights Crime Victims Compensation' [2008] New York State Bar Journal.

Bridgett N Shephard, 'Classifying Crime Victim Restitution: The Theoretical Arguments and Practical Consequences of Labeling Restitution As Either A Criminal or Civil Law Concept' (2014) 18 Lewis\& Clark Law Review $<$ https://law.lclark.edu/live/files/18298-lcb183art15shephardfinalpdf $>$.

Cortney E Lollar, 'What Is Criminal Restitution?' (2014) 93 Iowa Law Review. 
Dennis F DiBari, 'Restoring Restitution: The Role of Proximate Causation in Child Pornography Possession Cases Where Restitution Is Sought' [2011] Cardozo Law Review.

Fauzy Marasabessy, 'Restitusi Bagi Korban Tindak Pidana: Sebuah Tawaran Mekanisme Baru' (2015) 45 Jurnal Hukum dan Pembangunan <http://jhp.ui.ac.id/index.php/ home/article/viewFile/9/9>.

Frédéric Mégret, 'Justifying Compensation By The International Criminal Court's Victims Trust Fund: Lessons From Domestic Compensation Schemes' (2010) 36 Brooklyn Journal of International Law.

Gabriel H Teninbaum, 'Easing The Burden: Mediating Misdemeanor Criminal Matters' (2007) 62 Dispute Resolution Journal.

Jack B Weinstein, 'Some Benefit and Risks of Privatization of Justice Though ADR' [1996] Ohio State Journal on Dispute Resolution.

Juan Cardenas, 'The Crime Victim in the Prosecutorial Process' (1986) 9 Harvard Journal of Law \& Public Policy.

Julie Goldscheid, 'Crime Victim Compensation an a Post-9/11 World' (2004) 167 Tulane Law Review.

Karyn Ellen Polito, 'The Rights of Crime Victims in the Criminal Justice System: Is Justice Blind to the Victims of Crime?' (1990) 16 New England Journal on Criminal and Civil Confinement.

Lieutenant Colonel Warren G Foote, 'State Compensation for Victims of Crime' (1992) March Army Lawyer.

Linda F Frank, 'The Collection of Restitution: An Often Overlooked Service to Crime Victims' [1992] Saint John's Journal of Legal Commentary.

Marcus A Asner,[et.,al.], 'Restitution From the Victim Perspective-Recent Developments And Future Trends' (2013) 26 Federal Sentencing Reporter.

Mary Ellen Reimund, 'Mediation in Criminal Justice: A Restorative Approach' (2003) 46 Advocate.

Nicholas C Katsoris, 'The European Convention on the Compensation of Victims of Violent Crimes: A Decade of Frustration' (1990) 14 Fordham International Law Journal.

Susan E. GeganNicholas Ernesto Rodriguez, 'Victims' Roles in the Criminal Justice 
System: A Fallacy of Victim Empowerment?' (1992) 8 Saint John's Journal of Legal Commentary.

\section{Perundang-undangan}

Undang-undang Nomor 8 Tahun 1981 Tentang Hukum Acara Pidana.

Undang-undang Nomor 26 Tahun 2000 Tentang Pengadilan Hak Asasi Manusia.

Undang-undang Nomor 15 Tahun 2003 Tentang Pemberantasan Tindak Pidana Terorisme.

Undang-undang Nomor13 Tahun 2006 jo Undang-undang Nomor 31 Tahun 2014 Tentang Perlindungan Saksi dan Korban.

Undang-undang Nomor 21 Tahun 2007 Tentang Pemberantasan Tindak Pidana Perdagangan Orang.

Peraturan Pemerintah Nomor 3 Tahun 2002 Tentang Kompensasi, Restituti dan Rehabilitasi terhadap Korban Pelanggaran Hak Asasi Manusia yang Berat.

Peraturan Pemerintah Nomor 44 Tahun 2008 Tentang Pemberian Kompensasi, Restitusi dan Bantuan Kepada Saksi dan Korban.

HOW TO CITE: Mahrus Ali dan Ari Wibowo, 'Kompensasi dan Restitusi yang Berorientasi Pada Korban Tindak Pidana' (2018) 33 Yuridika. 